\title{
Distinct efficiencies of Impatiens necrotic spot virus transmission by five thrips vector species (Thysanoptera: Thripidae) of tospoviruses in Japan
}

\author{
Tamito SAKURAI, ${ }^{1, *}$ Toshiro InOUE ${ }^{2}$ and Shinya TsudA ${ }^{3}$ \\ ${ }^{1}$ Department of Biology and Environmental Sciences, National Agricultural Research Center for Tohoku Region; Morioka, Iwate \\ 020-0198, Japan \\ ${ }^{2}$ Department of Bioscience and Technology, Faculty of Agriculture, Iwate University; Morioka, Iwate 020-8550, Japan \\ ${ }^{3}$ Department of Plant Pathology, National Agricultural Research Center; Tsukuba, Ibaraki 305-8666, Japan \\ (Received 19 July 2003; Accepted 30 September 2003)
}

\begin{abstract}
Five thrips species known as vectors of tospoviruses in Japan, Frankliniella occidentalis, F. intonsa, Thrips setosus, $T$. palmi and T. tabaci, were studied for their transmission competence of Impatiens necrotic spot virus (INSV). The competence was examined for adults that acquired the virus as newly hatched larvae using a petunia leaf disk assay. No members of the genus Thrips transmitted the virus; the INSV-N protein was not detected in them by DAS-ELISA. On the other hand, two species of the genus Frankliniella were confirmed as vectors of INSV. Both sexes of $F$. occidentalis transmitted the virus efficiently (males: $80.5 \%$, females: $78.7 \%$ ). In $F$. intonsa, however, the transmission efficiency was relatively low and differed between the sexes (males: $18.3 \%$, females: $3.7 \%$ ). Most $F$ occidentalis adults showing ELISA-positive values transmitted INSV; however, only one third of ELISA-positive $F$. intonsa adults did so. The amounts of the INSV-N protein in ELISA-positive and transmitting adults were larger in F. occidentalis than in $F$. intonsa by sex. These results show that the transmission of INSV may be characteristic of the genus Frankliniella, and that $F$. occidentalis is probably the primary vector of INSV in Japan.
\end{abstract}

Key words: Impatiens necrotic spot virus; thrips vector; transmission competence; virus accumulation

\section{INTRODUCTION}

The genus Tospovirus, which belongs to the family Bunyaviridae, causes severe economic losses in a wide range of crops and flowers worldwide (German et al., 1992; Peters, 1998). Impatiens necrotic spot virus (INSV) is a tospovirus that has been associated with disease outbreaks in numerous flower species in greenhouses in temperate areas such as North America and Europe (Daughtrey et al., 1997). Because tospoviruses are transmitted by at least ten thrips species, Frankliniella occidentalis (Pergande), F. schultzei (Trybom), F. intonsa (Trybom), F. fusca (Hinds), F. bispinosa (Morgan), F. zucchini Nakahara and Monteiro, T. setosus Moulton, T. palmi Karny, T. tabaci Lindeman and Scirtothrips dorsalis Hood (Thysanoptera: Thripidae) (Mound, 2002), researchers must first determine the primary vector species of the tospovirus occurring in a specific area to develop effective management plans for the virus disease.

A previous study reported that $F$. occidentalis transmitted INSV with a high efficiency, but that $F$. schultzei, F. intonsa and T. tabaci did not (Wijkamp et al., 1995). However, it has been so far reported that there exists intraspecific variation in transmission competence of a tospovirus, Tomato spotted wilt virus (TSWV), by thrips vector species: the transmission efficiency of TSWV varied among populations in F. schultzei (Sakimura, 1969; Wijkamp et al., 1995), in F. occidentalis (van de Wetering et al., 1999a; Sakurai et al., 2002) and in T. tabaci (Wijkamp et al., 1995; Chatzivassiliou et al., 1999, 2002), and between sexes in F. occidentalis (Sakurai et al., 1998, 2002; van de Wetering et al., 1998, 1999b) and in T. tabaci (Chatzivassiliou et al., 1999). These findings suggest that the transmission efficiency of a newly occurring tospovirus in a specific area should be examined for thrips cultures originating from more than one population and for both sexes in all vector species of tospoviruses that live there. By doing so, we may also gain insight into the specificity of the transmission of tospovirus by thrips.

\footnotetext{
* To whom correspondence should be addressed at: E-mail: tsakurai@affrc.go.jp
} 
In Japan, INSV was first recorded on verbenas in 1999 (Iriyama et al., 1999), and occurrences of INSV infection have increased for various flower species in recent years (Fuji and Yamamoto, 2000; Tanina et al., 2001; Goto et al., 2001). Although five thrips species, F. occidentalis, F. intonsa, T. setosus, T. palmi and T. tabaci, have been confirmed as vectors of tospoviruses in Japan (Kobatake et al., 1976, 1984; Iwaki et al., 1984; Kato and Katayama, 1998; Sakurai et al., 1998; Inoue et al., 2002), the vector species of INSV have remained unknown. In the present study, adults of these five thrips species, after acquiring INSV at the first larval instar stage, were examined for their potential for virus accumulation and transmission to determine the primary vector species in Japan. Each thrips species was collected from two different populations, and the transmission efficiency in each population was measured for each sex, respectively, in consideration of the potential for intraspecific variation.

\section{MATERIALS AND METHODS}

Thrips. We used the five thrips species known as vectors of tospoviruses in Japan: F. occidentalis, F. intonsa, T. setosus, T. palmi and T. tabaci. They were collected on various crops and flowers in several populations in Japan (Table 1). Voucher specimens were deposited in the Laboratory of Insect Resources, Faculty of Agriculture, Tokyo University of Agriculture. All larvae and pupae of these thrips species were reared on germinated seeds of the broad bean, Vicia faba L. Adult colonies of $F$. occidentalis, F. intonsa, T. tabaci and one T. palmi population (T.pOk) were confined in a polymethacrylate cylinder cage $(80 \mathrm{~mm}$ diameter, $50 \mathrm{~mm}$ tall) with tea pollen, Camellia sinensis (L.) O. Kuntze, as described by Murai and Loomans (2001). In another T. palmi population (T.pKc) and T. setosus, adults were maintained on leaves of the cucumber, Cucumis stativus L. and the kidney bean, Phaseolus vulgaris L., respectively. The rearing conditions were $23 \pm 1{ }^{\circ} \mathrm{C}$ and a $16: 8 \mathrm{~L}: \mathrm{D}$ photoperiod.

Virus. The Japanese isolate INSV-J, originating from Verbena $\times$ hybrida cv. Hanatemari in Tsukuba $\left(36^{\circ} 02^{\prime} \mathrm{N}-140^{\circ} 04^{\prime} \mathrm{E}\right)$, was used in all the experiments. The nucleotide and amino acid sequence of the nucleocapsid $(\mathrm{N})$ protein of this isolate share $98.2 \%$ and $99.2 \%$ identity, respectively, with those of the Netherlands isolate NL-07 (de Ávila et al., 1992; de Haan et al., 1992; Nagano and Tsuda, 2003). The virus isolate was maintained by thrips inoculation on leaf disks (6 mm diameter) of Petunia $\times$ hybrida cv. Polo Blue and subsequently by mechanical inoculation on Nicotiana benthamiana Domin. and Impatiens sp. plants.

INSV acquisition by thrips. Impatiens sp. was chosen as an acquisition host for INSV by thrips because the virus distributes evenly throughout the plant (Wijkamp et al., 1995), and larvae of all the thrips species used in this study survived on it until the adult stage. All leaves used as a virus acquisi-

Table 1. Collection data of thrips species used in this study; all are known vectors of tospoviruses in Japan.

\begin{tabular}{llllll}
\hline \multicolumn{1}{c}{ Species } & Population & $\begin{array}{c}\text { City, Prefecture } \\
(\text { Geographic coordinates })\end{array}$ & Original host & Collection year & Collector \\
\hline Frankliniella occidentalis & F.oIw & $\begin{array}{l}\text { Morioka, Iwate } \\
\left(39^{\circ} 42^{\prime} \mathrm{N}-141^{\circ} 09^{\prime} \mathrm{E}\right)\end{array}$ & Egg plant & 1999 & T. Sakurai \\
& F.oKc & $\begin{array}{l}\text { Nankoku, Kochi } \\
\left(33^{\circ} 34^{\prime} \mathrm{N}-133^{\circ} 38^{\prime} \mathrm{E}\right)\end{array}$ & Egg plant & 1998 & T. Sakurai \\
& F.ilw & Morioka, Iwate & Marigold & 2002 & T. Sakurai \\
F. intonsa & F.iKc & Nankoku, Kochi & Green pepper & 1998 & T. Sakurai \\
Thrips setosus & T.sIw & Morioka, Iwate & Soybean & 2002 & T. Inoue \\
& T.sKc & Nankoku, Kochi & Glory lily & 2002 & K. Komi \\
T. palmi & T.pKc & Nankoku, Kochi & Egg plant & 2002 & K. Komi \\
& T.pOk & Sanyo-cho, Okayama & Egg plant & 1993 & T. Nagai \\
T. tabaci & T.tIw & Morioka, Iwate & Leek & 2001 & T. Inoue \\
& T.tSm & Izumo, Shimane & Onion & 1996 & T. Murai
\end{tabular}


tion source were tested for the presence of the virus with simplified rapid immunofilter paper assay (RIPA) (Tsuda et al, 1992; Ohki and KameyaIwaki, 1996) using commercially available immunostrips (Agdia, Inc., USA). Newly hatched larvae up to $8 \mathrm{~h}$ old were given an acquisition access period of $16 \mathrm{~h}$ on INSV-infected Impatiens sp. leaves in a Petri dish whose top end was covered with a stretched laboratory film (Parafilm $\mathrm{M}^{\circledR}$, Pechiney Plastic Packaging, Inc., USA). After this period, only larvae that stayed on the leaves were transferred to healthy germinated broad bean seeds and reared until they became adults. All experiments were carried out at $23 \pm 1^{\circ} \mathrm{C}$ with a $16: 8 \mathrm{~L}: \mathrm{D}$ photoperiod.

Thrips transmission assay. Transmission efficiency of INSV was examined for adults of five thrips species using petunia leaf disks $(6 \mathrm{~mm}$ diameter) of Petunia $\times$ hybrida cv. Polo Blue (Wijkamp and Peters, 1993). Adult thrips, four days after emergence, were individually dropped into a $1.5 \mathrm{ml}$ tube and allowed to feed on a leaf disk to determine the transmission competence in two successive inoculation access periods (IAPs) of $48 \mathrm{~h}$. After each IAP, leaf disks were floated on water for two days in 48-well plates for symptom development. If at least one leaf disk developed local lesions in two IAPs, the thrips tested was considered to be a transmitter of INSV. Each population of the five thrips species was tested two or three times with more than 20 adults per repetition. After this assay, over 40 adults per population except $T$. tabaci were stored at $-80^{\circ} \mathrm{C}$ until testing in a double-antibody sandwich enzyme-linked immunosorbent assay (DAS-ELISA) to investigate the relationship between the transmission and accumulation of the virus in them. Because populations of $T$. tabaci consist of females only (i.e. thelytoky), we stored 21 females per population for DAS-ELISA.

DAS-ELISA. The relative amount of virus antigen in individual adult thrips was determined by DAS-ELISA using polyclonal antibodies (PAbs) raised against the N protein of INSV-J (Kawano et al., 2003). Each well of microtiter plates was coated with $100 \mu \mathrm{l}$ of a coating buffer $(0.05 \mathrm{M}$ sodium carbonate, $\mathrm{pH} 9.6$ ) with $1.5 \mu \mathrm{g} / \mathrm{ml} \mathrm{IgG}$ of $\mathrm{PAb}$ and incubated for $3 \mathrm{~h}$ at $37^{\circ} \mathrm{C}$. After blocking non-specific binding sites with $100 \mu \mathrm{l}$ of $1 \%$ bovine serum albumin (BSA) in PBS $(0.14 \mathrm{M} \mathrm{NaCl}$, $1 \mathrm{mM} \mathrm{KH}_{2} \mathrm{PO}_{4}, 8 \mathrm{mM} \mathrm{Na} \mathrm{HPO}_{4}, 2.5 \mathrm{mM} \mathrm{KCl}, \mathrm{pH}$
7.4), the wells were loaded with $100 \mu$ of thrips extracts homogenized with a micro pestle in a sample buffer ( $2 \%$ polyvinylpyrrolidone, MW 40,000, $0.2 \%$ BSA in PBS, including $0.05 \%$ Tween 20 : PBS-T), and incubated overnight at $4^{\circ} \mathrm{C}$. Six healthy thrips extracts per plate were used as controls. One hundred microliters of IgG-alkaline phosphatase conjugate $(1.5 \mu \mathrm{g} / \mathrm{ml})$ in a sample buffer was added to each well and incubated for $3 \mathrm{~h}$ at $37^{\circ} \mathrm{C}$. Plates were rinsed more than three times between each step with PBS-T. In the substrate step, $100 \mu \mathrm{l}$ of $1 \mu \mathrm{g} / \mathrm{ml} p$-nitrophenyl phosphate in $0.01 \mathrm{M}$ diethanolamine buffer, $\mathrm{pH} 9.8$, was added to each well. The reaction was allowed to proceed for $1 \mathrm{~h}$ at room temperature, and then absorbance values were determined with an ELISA-reader at $405 \mathrm{~nm}\left(A_{405}\right)$. Samples that gave ELISA readings greater than the mean plus four times the standard deviation of the healthy control thrips were considered to be positive. The $A_{405}$ values were corrected by subtracting the average of the buffer control from sample values.

Statistics. Analyses of frequencies of transmission experiments were conducted by Fisher's exact probability test. Differences in INSV-N protein titer between sources and the effect of interaction between sources were tested by one- or two-way analysis of variance (ANOVA) (Sokal and Rohlf, 1998).

\section{RESULTS}

\section{Efficiency of INSV transmission by five thrips species}

Adults of two thrips species in the genus Frankliniella, $F$. occidentalis and $F$. intonsa, transmitted INSV to petunia leaf disks. Although the transmission efficiency was similar between different populations of the same sex and species, a significant difference was found between $F$. occidentalis and F. intonsa by sex (males: $p<0.0001$, females: $p<0.0001$ ) (Fig. 1). The efficiency was considerably high in both sexes of F. occidentalis (ca. $80 \%$ ), but was low and significantly different between sexes in F. intonsa $(18.3 \%$ of males, $3.7 \%$ of females; $p<0.0001$ ) (Fig. 1). On the other hand, adults in the genus Thrips, i.e., T. setosus, T. palmi and $T$. tabaci, were unable to transmit the virus (Fig. 1). 


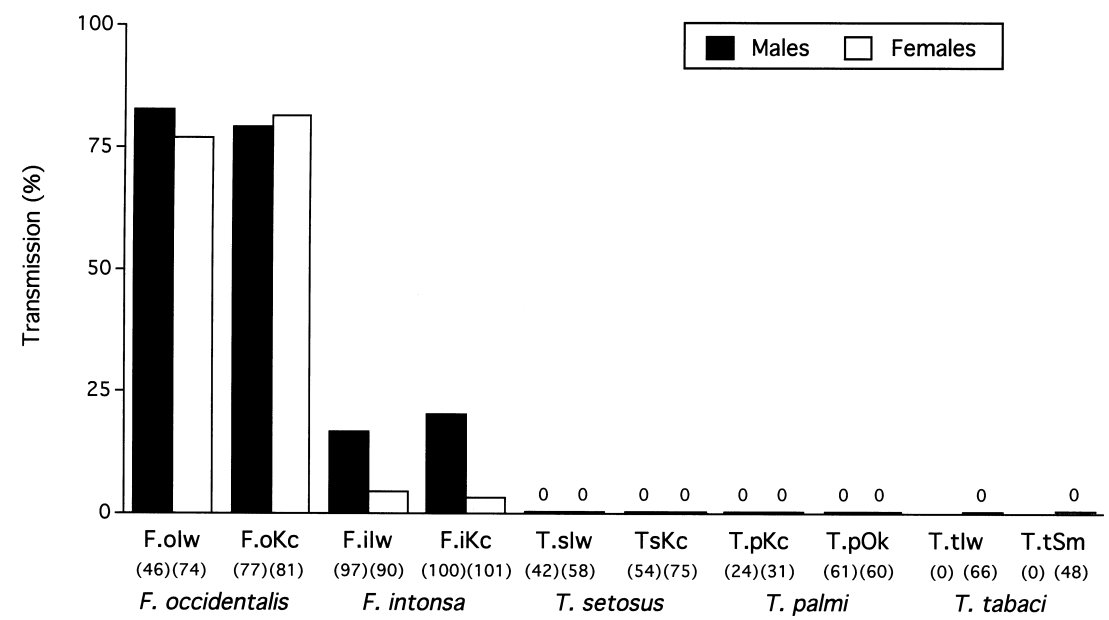

Fig. 1. Efficiency of Impatiens necrotic spot virus transmission by adults of five thrips species known as tospoviruses vectors in Japan. Newly hatched larvae were given an acquisition access period of $16 \mathrm{~h}$ on INSV-infected Impatiens leaves. Values in parentheses represent the number of thrips tested.

\section{Relationship between INSV infection and trans- missibility}

Figure 2 shows the frequency distributions for three different combinations of INSV infection and transmissibility in males and females of each species, respectively. No ELISA-negative adults, which were individuals confirmed as non-viruliferous thrips for INSV using DAS-ELISA, transmitted the virus in any thrips species tested. Since the frequency distributions as well as the transmission efficiencies were identical or similar between different populations of the same sex and species, those data are shown for each species by joining data of the two populations whose sample sizes were almost the same. All adults of the three species in the genus Thrips were both non-transmitters and ELISA-negative (Fig. 2). Over $90 \%$ of both males and females in F. occidentalis were ELISA-positive, compared to $63.3 \%$ of the males and $46.5 \%$ of the females in F. intonsa (Fig. 2). There was a significant difference in the percentage of ELISA-positive thrips between the two Frankliniella species by sex (males: $p<0.01$; females: $p<0.0001)$. In F. occidentalis, most ELISA-positive thrips were transmitters $(89.7 \%$ of males, $84.8 \%$ of females), whereas in F. intonsa, $41.9 \%$ of males and $15.0 \%$ of females among ELISA-positive adults transmitted INSV (Fig. 2). The percentage of transmitters in ELISA-positive thrips differed significantly between the two species in each sex (males: $p<0.0001$; females: $p<0.0001$ ).

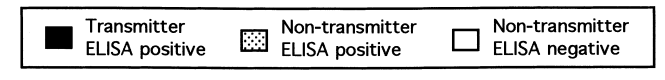

a) Males

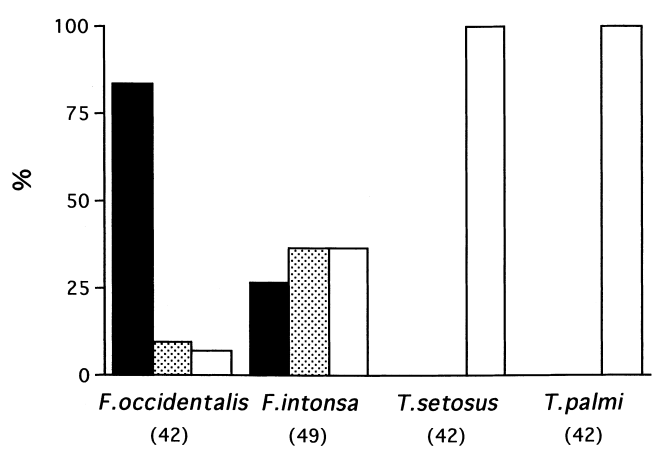

b) Females

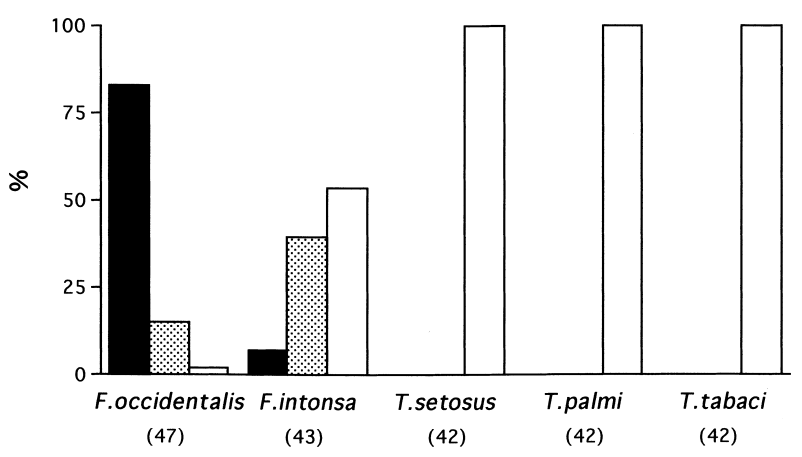

Fig. 2. Percentages of adults of five thrips species for different combinations of Impatiens necrotic spot virus infection and transmissibility (a: males; b: females). Newly hatched larvae were given an acquisition access period of $16 \mathrm{~h}$ on INSVinfected Impatiens leaves. Individuals that gave ELISA readings greater than the mean plus four times the standard deviation of the healthy control thrips were considered to be positive. Values in parentheses represent the number of thrips tested. 


\begin{tabular}{|l} 
Transmitter \\
ELISA positive
\end{tabular}$\quad \begin{aligned} & \text { Non-transmitter } \\
& \text { ELISA positive }\end{aligned} \square \begin{aligned} & \text { Non-transmitter } \\
& \text { ELISA negative }\end{aligned} \quad \begin{aligned} & \text { Healthy } \\
& \text { thrips }\end{aligned}$

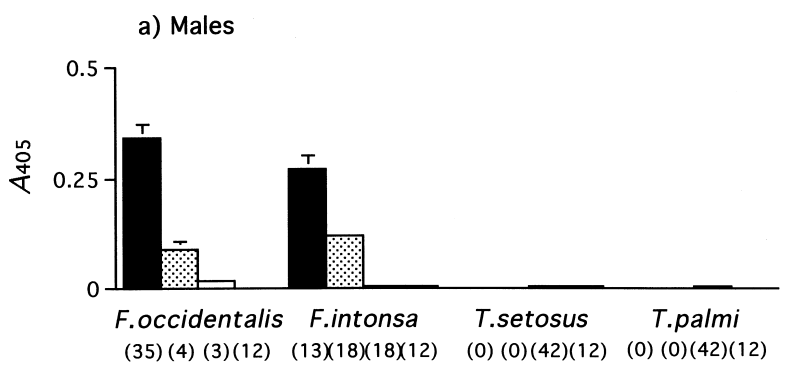

b) Females

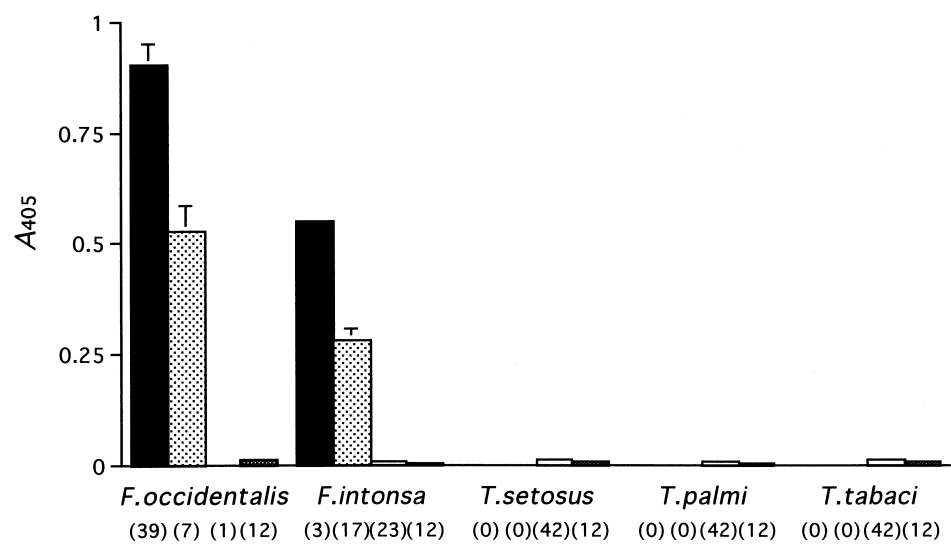

Fig. 3. ELISA readings $\left(A_{405}\right.$; mean $\left.\pm \mathrm{SE}\right)$ for Impatiens necrotic spot virus $\mathrm{N}$-protein titer in adults of five thrips species for different combinations of the virus infection and transmissibility (a: males; b: females). Newly hatched larvae were given an acquisition access period of $16 \mathrm{~h}$ on INSV-infected Impatiens leaves. Individuals that gave ELISA readings greater than the mean plus four times the standard deviation of the healthy control thrips were considered to be positive. Values in parentheses represent the number of thrips tested.

\section{INSV-N protein titer in thrips}

The ELISA readings for the INSV-N protein titer were similar between different populations of the same sex and species, so those were also shown for each species by joining data of the two populations in Fig. 3. In the three Thrips species, all adult thrips, which were both non-transmitters and ELISA-negative, were almost equal to healthy ones in the readings (Fig. 3). The accumulation of INSV was detected in adults of $F$. occidentalis and $F$. intonsa (Fig. 3). In ELISA-positive adults of both species, significant differences were observed in ELISA readings between the sexes $(F=77.247$, $p<0.0001)$ and between species $(F=70.757$, $p<0.0001)$; the effect of the interaction between them was significant $(F=24.343, p<0.0001)$, indicating that the difference in readings between species was smaller in males (mean $\pm \mathrm{SE}, F$. occidentalis: $0.309 \pm 0.026, \quad n=39 ; \quad F . \quad$ intonsa:
$0.183 \pm 0.019, n=31)$ than in females (F. occidentalis: $0.806 \pm 0.042, n=46 ; \quad F$. intonsa: $0.323 \pm$ $0.032, n=20$ ). There were also significant differences in readings between transmitters and nontransmitters in ELISA-positive males (F. occidentalis: $F=10.501, p<0.01 ; F$ intonsa: $F=28.952$, $p<0.0001)$ and in positive females (F. occidentalis: $F=9.328, \quad p<0.01 ; \quad F . \quad$ intonsa: $\quad F=16.397$, $p<0.001$ ), suggesting that successful transmission required large amounts of virus in the transmitters (Fig. 3). Besides, in transmitters, the readings were significantly different between sexes $(F=31.632$, $p<0.0001)$ and between species $(F=6.661$, $p<0.05)$; the effect of the interaction between them was not significant $(F=2.829, p=0.096)$ (Fig. 3).

\section{DISCUSSION}

The present study reconfirmed that F. occiden- 
talis is a vector species of INSV. This thrips had been reported as the only vector species of the virus (Wijkamp and Peters, 1993; DeAngelis et al., 1994; Wijkamp et al., 1995; van de Wetering et al., 1999a). Wijkamp et al. (1995) indicated that $F$. schultzei, F. intonsa and T. tabaci were unable to acquire, replicate and transmit the virus. However, our results showed that adults of $F$. intonsa were capable of accumulating and transmitting INSV, whereas adults of three species in the genus Thrips, T. setosus, T. palmi and T. tabaci, were not, suggesting that competences of accumulation and transmission of INSV are likely to be unique to several species in the genus Frankliniella. Inoue et al. (2002) found that the amounts of TSWV-N protein decreased drastically from larval to adult stages in the genus Thrips, T. setosus, T. palmi, T. tabaci and T. hawaiiensis (Morgan), although adults of T. setosus and T. tabaci accumulated and transmitted the virus with low efficiencies; on the other hand, large amounts of the virus were observed in both stages in the genus Frankliniella, $F$. occidentalis and F. intonsa, which proved an efficient vector of TSWV. Therefore, TSWV and INSV are probably more compatible with the genus Frankliniella than the genus Thrips. The successful transmission of INSV seems to be particularly dependent on the genus Frankliniella.

Inconsistency in the ability of INSV transmission by $F$. intonsa between studies may be explained by intraspecific variation. Several researchers reported that the efficiency of TSWV transmission by vector thrips species was variable among cohorts originating from different populations (Sakimura, 1969; Wijkamp et al., 1995; van de Wetering et al., 1999a; Chatzivassiliou et al., 1999, 2002; Sakurai et al., 2002). The attribute of INSV transmission in the two $F$. intonsa populations tested in this study, which had almost the same transmission efficiency despite originating from quite separated areas, is likely to be different from that of the population used in Wijkamp et al. (1995).

Although $F$. occidentalis and $F$. intonsa originating from Japanese populations were confirmed as vector species of INSV in the current study, the transmission competence differed considerably between them. The efficiencies were about $80 \%$ in $F$. occidentalis and lower than $20 \%$ in $F$. intonsa. This high transmission competence of $F$. occidentalis has also been reported in previous studies (Wijkamp and Peters, 1993; Wijkamp et al., 1995; van de Wetering et al., 1999a); on the other hand, $F$. intonsa has been considered to be a non-vector of INSV. These findings suggest that, in Japan, F. occidentalis is a primary vector species of INSV and $F$. intonsa is an inefficient. Diseases caused by INSV are more commonly detected in greenhouse flower crops and rarely occur in field vegetable ones (Daughtrey et al., 1997). Because F. occidentalis is a serious pest of greenhouse crops (Brødsgaard, 1989; Tommasini and Maini, 1995; Stack et al., 1997), INSV will cause critical damage to greenhouse flower production in Japan if appropriate management for $F$. occidentalis is not undertaken.

F. intonsa males transmitted the virus at a higher rate than females. Such higher efficiency for males has been reported for TSWV transmission by F. occidentalis (Sakurai et al., 1998, 2002; van de Wetering et al., 1998; 1999b) and by T. tabaci (Chatzivassiliou et al., 1999), suggesting that it may be a common phenomenon in the transmission of TSWV and INSV by thrips, although the mechanism that leads to the variation remains to be elucidated. However, the inter-sexual difference in INSV transmission was not observed in F. occidentalis. When $F$. occidentalis adults transmitted TSWV with a high efficiency, the difference between sexes was smaller than with low-efficiency transmitters (van de Wetering et al., 1999b) and in T. tabaci (Chatzivassiliou et al., 2002). Since the efficiency of INSV transmission by $F$. occidentalis was fairly high and that by $F$. intonsa was low, distinctions in efficiency between the sexes could be observed in only F. intonsa.

The inter-specific variation in INSV transmission by adults of $F$. occidentalis and $F$. intonsa is probably related to virus accumulation. When newly hatched larvae of $F$. occidentalis were given an AAP of $16 \mathrm{~h}$, most of them became ELISA-positive adults, of which over $85 \%$ transmitted the virus. This high proportion of viruliferous individuals is possibly the main reason for the high efficiency of transmission by $F$. occidentalis. On the other hand, about $55 \%$ of $F$. intonsa adults were ELISA-positive and only $30 \%$ of them were transmitters. In viruliferous thrips of both species, the accumulation of INSV-N protein was significantly larger in transmitters than in non-transmitters. 
These results suggest that the efficient replication of INSV that leads to successful transmission would occur in a number of $F$. occidentalis adults; however, in F. intonsa, only about half of the adults can accumulate the virus in them, and only a small percentage of them can carry sufficient amounts of virus to transmit it.

In conclusion, the results of this study show that F. occidentalis and F. intonsa are undoubtedly vector species of INSV; the former, as the primary vector species, is extremely efficient at transmission due to the high levels of virus accumulation in adults. Compared with $F$. occidentalis, F. intonsa is unlikely to be a serious threat to growers of greenhouse flower crops because of its inefficient transmission of INSV. We also propose that two thrips vector species of tospoviruses, $T$. setosus and $T$. palmi, should be added to the list of non-vector species of INSV along with T. tabaci.

\section{ACKNOWLEDGEMENTS}

We wish to thank Dr. S. Okajima (Tokyo University of Agriculture) for identifying thrips species and the deposit of voucher specimens. We are indebted to Drs. T. Murai (National Institute of Fruit Tree Science), K. Nagai (Shimane Agricultural Experiment Station) and K. Komi (Kochi Prefectural Agriculture Research Center) for providing cultures of thrips populations and to Dr. T. Kawano (Japan Plant Protection Association) for supplying the DAS-ELISA kit. Dr. H. Nagano (Japan Society for the Promotion of Science) gave us useful information on the sequence data of the INSV-N protein. Seeds of $N$. benthamiana were kindly provided by Leaf Tobacco Research Laboratory, Japan Tobacco Inc. (JT). We are also grateful to Drs. T. Omura (National Agricultural Research Center), T. Iwanami, M. Okuda (National Agricultural Research Center for Kyushu Okinawa Region) and A. Kawai (National Institute of Vegetable and Tea Science) for invaluable comments on the experimental design in this study and to two anonymous reviewers for their critical reading of the manuscript.

\section{REFERENCES}

Brødsgaard, H. F. (1989) Frankliniella occidentalis (Thysanoptera; Thripidae) - a new pest in Danish glasshouses: A review. Tidssk. Planteavl. 93: 83-91.

Chatzivassiliou, E. K., T. Nagata, N. I. Katis and D. Peters (1999) Transmission of tomato spotted wilt tospovirus by Thrips tabaci populations originating from leek. Plant Pathol. 48: 700-706.

Chatzivassiliou, E. K., D. Peters and N. I. Katis (2002) The efficiency by which Thrips tabaci populations transmit Tomato spotted wilt virus depends on their host preference and reproductive strategy. Phytopathology 92: 603-609.

Daughtrey, M. L., R. K. Jones, J. W. Moyer, M. E. Daub and J.
R. Baker (1997) Tospoviruses strike the greenhouse industry: INSV has become a major pathogen on flower crops. Plant Dis. 81: 1220-1230.

DeAngelis, J. D., D. M. Sether and P. A. Rossignol (1994) Transmission of impatiens necrotic spot virus in peppermint by western flower thrips (Thysanoptera, Thripidae). J. Econ. Entomol. 87: 197-201.

de Ávila, A. C., P. De Haan, R. Kormelink, R. de O. Resende, R. W. Goldbach and D. Peters (1992) Characterization of a distinct isolate of tomato spotted wilt virus (TSWV) from Impatiens sp. in the Netherlands. J. Phytopathol. 134: 133-151.

de Haan, P., A. C. de Ávila, R. Kormelink, A. Westerbroek, J. J. L. Gielen, D. Peters and R. Goldbach (1992) The nucleotide sequence of the S RNA of Impatiens necrotic spot virus, a novel tospovirus. FEBS Letters 306: 27-32.

Fuji, S. and H. Yamamoto (2000) Occurrence of Impatiens necrotic spot virus (INSV) in Akita Prefecture. Ann. Rept. Plant Prot. North Japan 51: 122-125 (in Japanese with English summary).

German, T. L., D. E. Ullman and J. W. Moyer (1992) Tospoviruses: diagnosis, molecular biology, phylogeny, and vector relationships. Ann. Rev. Phytopathol. 30: 315-348.

Goto, T., H. Sazarashi, H. Nozawa, K. Nakayama and T. Natsuaki (2001) Necrotic spot disease of cyclamen (Cyclamen persicum) and exacum (Exacum affine) caused by Impatiens necrotic spot virus (INSV). Ann. Rept. Kanto-Tosan Plant Prot. Soc. 48: 97-100 (in Japanese with English summary).

Inoue, T., T. Sakurai, T. Murai and T. Maeda (2002) Accumulation and transmission of TSWV at larval and adult stages in six thrips species: distinct patterns between Frankliniella and Thrips. In Thrips and Tospoviruses: Proceedings of the 7th International Symposium on Thysanoptera (R. Marullo and L. Mound eds.). Australian National Insect Collection, Canberra, pp. 59-65.

Iriyama, K., H. Hirata, K. Oshima and S. Namba (1999) Impatiens necrotic spot virus detected in Verbena hybrida. Ann. Phytopathol. Soc. Jpn. 65: 379 (Abstr. in Japanese).

Iwaki, M., Y. Honda, K. Hanada, H. Tochihara, T. Yonaha, K. Hokama and T. Yokoyama (1984) Silver mottle disease of watermelon caused by tomato spotted wilt virus. Plant Dis. 68: 1006-1008.

Kato, H. and H. Katayama (1998) Virus diseases transmitted by Frankliniella occidentalis (Pergande). Plant Protect. 52: 18-20 (in Japanese).

Kawano, T., Y. Takagi, Y. Takahashi, T. Omura and S. Tsuda (2003) Production of antibody to Impatiens necrotic spot virus isolated in Japan and development of serological diagnosis techniques. Jpn. J. Phytopathol. 69: 344 (Abstr. in Japanese).

Kobatake, H., T. Osaki and T. Inouye (1984) Reservoirs of tomato spotted wilt virus in Nara Prefecture. Ann. Phytopath. Soc. Jpn. 50: 541-544.

Kobatake, H., T. Osaki, A. Yoshioka and T. Inouye (1976) Spotted wilt disease of tomatoes in Japan. Ann. Phytopath. Soc. Jpn. 42: 287-294. 
Mound, L. A. (2002) So many thrips - so few tospoviruses? In Thrips and Tospoviruses: Proceedings of the 7th International Symposium on Thysanoptera (R. Marullo and L. Mound eds.). Australian National Insect Collection, Canberra, pp. 15-18.

Murai, T. and A. J. M. Loomans (2001) Evaluation of an improved method for mass-rearing of thrips and a thrips parasitoid. Entomol. Exp. Appl. 101: 281-289.

Nagano, H. and S. Tsuda (2003) Determination of the complete nucleotide sequence of Impatiens necrotic spot virus S-RNA. Jpn. J. Phytopathol. 69: 344 (Abstr. in Japanese).

Ohki, S. and M. Kameya-Iwaki (1996) Simplifying of the rapid immunofilter paper assay for faster detection of plant viruses: simplified RIPA. Ann. Pytopathol. Soc. Jpn. 62: 240-242.

Peters, D. (1998) An updated list of plant species susceptible to tospoviruses. In Recent Progress in Tospovirus and Thrips Research (D. Peters and R. Goldbach eds.). Wageningen Agricultural University, Wageningen, Netherlands, pp. 107-110.

Sakimura, K. (1969) A comment on the color forms of Frankliniella schultzei (Thysanoptera: Thripidae) in relation to transmission of the tomato-spotted wilt virus. Pac. Insects 11: 761-762.

Sakurai, T., T. Inoue and T. Murai (2002) Intraspecific variation in transmission of TSWV by Frankliniella occidentalis results from distinct virus accumulation. In Thrips and Tospoviruses: Proceedings of the 7th International Symposium on Thysanoptera (R. Marullo and L. Mound eds.). Australian National Insect Collection, Canberra, pp. 51-57.

Sakurai, T., T. Murai, T. Maeda and H. Tsumuki (1998) Sexual differences in transmission and accumulation of tomato spotted wilt virus in its insect vector Frankliniella occidentalis (Thysanoptera: Thripidae). Appl. Entomol. Zool. 33: 583-588.

Sokal, R. R. and Rohlf, F. J. (1998) Biometry. 3rd ed. Freeman and Co., New York. 887 pp.

Stack, P. A., L. B. Stack and F. A. Drummond (1997) A twoyear grower survey of thrips and Tospovirus incidence and management in Maine greenhouses. J. Agric. Entomol. 14: 205-224.

Tanina, K., K. Inoue, H. Date, M. Okuda, K. Hanada, H. Nasu and S. Kasuyama (2001) Necrotic spot disease of cineraria caused by Impatiens necrotic spot virus. Jpn. J. Phytopathol. 67: 42-45 (in Japanese with English summary).

Tommasini, M. G. and S. Maini (1995) Frankliniella occidentalis and other thrips harmful to vegetable and ornamental crops in Europe. In Biological Control of Thrips Pests (A. J. L. Loomans, J. C. van Lenteren, M. G. Tommasini, S. Maini and J. Riudavets eds.). Wageningen Agricultural University Papers 95-1, Veenman, Wageningen, pp. 1-42.

Tsuda, S., M. Kameya-Iwaki, K. Hanada, Y. Kouda, M. Hikata and K. Tomaru (1992) A novel detection and isolation technique for plant viruses: Rapid immunofilter paper assay (RIPA). Plant Dis. 76: 466-469.

van de Wetering, F., J. Hulshof, K. Posthuma, P. Harrewijn, R. Goldbach and D. Peters (1998) Distinct feeding behavior between sexes of Frankliniella occidentalis results in higher scar production and lower tospovirus transmission by females. Entomol. Exp. Appl. 88: 9-15.

van de Wetering, F., M. van der Hoek, R. Goldbach, C. Mollema and D. Peters (1999a) Variation in tospovirus transmission between populations of Frankliniella occidentalis (Thysanoptera: Thripidae). Bull. Entomol. Res. 89: 579-588.

van de Wetering, F., M. van der Hoek, R. Goldbach and D. Peters (1999b) Differences in tomato spotted wilt virus vector competency between males and females of Frankliniella occidentalis. Entomol. Exp. Appl. 93: 105-112.

Wijkamp, I., N. Almarza, R. Goldbach and D. Peters (1995) Distinct levels of specificity in thrips-transmission of tospoviruses. Phytopathology 85: 1069-1074.

Wijkamp, I. and D. Peters (1993) Determination of the median latent period of two tospovirus in Frankliniella occidentalis, using a novel leaf disk assay. Phytopathology 83: 986-991. 